To conclude, the volume adequately responds to many of the theoretical challenges that Zadie Smith's fiction has so far generated. It launches a dialogue, and the emerging, valuable exercises in scholarship in one collection assign yet another dimension to the moral and aesthetic imperative that Smith shares with Forster: "Only connect!"

Tamás Juhász

\section{Commentators, Editors, Publishers, and Other Readers}

Philip Goldstein \& James L. Machor (ed.), New Directions in American Reception Study (Oxford \& New York: Oxford University Press, 2008)

The problem with reception studies is that there is nothing to read. As one cannot extract a reading from a reader's brain to subject it to scrutiny under a microscope, there appears to be no way but to rely on some kind of output on the readers' part when investigating what has traditionally been conceived of as the opposite of production: reception. However trivial and banal this statement may appear, it has far-reaching theoretical and practical consequences, as shown by the essays in the 2008 collection New Directions in American Reception Study, which stemmed from a conference held at the University of Delaware three years before. In fact, the collection can be read as explorations of various strategies aimed at circumventing this problem.

As in the case of many books presenting novel directions in literary and cultural studies, ${ }^{1}$ the introduction to this collection also heralds its subject as one that will finally be able to unify such age-old binaries as the historical as opposed to the rhetorical, to accommodate critical approaches of the $21^{\text {st }}$ century, and, thus, serve as a new centre not only to the now-fragmented field of literary, but also to the wider area of cultural studies. But when I read that the archenemy of reception studies - criticism which clings to the possibility of a fixed, authoritative meaning - "the traditional essentialist method has restricted literary study and repeatedly produced impasses," and that reception study is the one that "opens literary study to its twenty-first-century constituents" (xxv), I could not help but think of the criticism of Roland Barthes's "The Death of the Author," suggesting that Barthes had had to construct a dummy Author-God in order to be able to denounce what had, arguably, never been there. ${ }^{2}$

The editors divided the 19 essays in the anthology into five groups according to their subject matter. The collection starts with more theoretical writings, and continues with the most extensive group, analyses which are embedded in more traditional literary criticism. These are followed by three essays which are concerned with the "ordinary" reader or print culture from a historical perspec- 
tive, and three more analysing the latest branches of media: film, TV, and Internet fandom. The two essays in the fifth group are in dialogue with the preceding ones, and serve as postscripts to the anthology. Toby Miller's aptly titled “The Reception Deception," I felt, could have actually served as a more intriguing introduction to the whole collection.

The present introduction also has its special merits. It surveys the history of reception study, from being part of the investigation of authors' development guided by contemporaneous feedback to reacting against the "affective fallacy" of New Criticism, with as diverse views on the relationship between text and reader as those of David Bleich, Wolfgang Iser, Hans Robert Jauss, or Stanley Fish. It also provides summaries of all articles separately, which must, I feel, be greeted by anyone not familiar with the latest achievements in reception studies. As the essays lack abstracts, however, I think the summaries could have been even more useful if they had been prefaced to the essays directly.

Despite some irregularities in the index (a handy and welcome feature in any anthology) and occasional typographical errors, the book offers an invaluable insight into the latest achievements and concerns in reception study and, as I shall argue, in a realm even wider than that.

Disregarding somewhat the categories set up by the editors let me proceed by investigating common strategies of the essays which deal with the problem of the inherent inaccessibility of reception and reading in the strict sense. As we shall see, many of these approaches point toward a stage in reception and cultural studies which may have been passed, but is certainly ahead of us: the blurring of the distinction between reception and production.

The first strategy might be described as one that focuses on the output of "expert" readers, who occupy themselves with writing reading(s). These studies often cite published reviews or scholarly analyses as indices to reception, and frequently dwell on the disparity of interpretative communities separated either by time or culture. James L. Machor investigates the antebellum reception of Herman Melville's short stories, and concludes that interpretative assumptions regarding the reliability of the narrator appear to have been considerably different from those of our day. Steven Mailloux's account is, in effect, reading reading reading-reading, as the bulk of his essay reviews reactions to Azar Nafisi's Reading Lolita in Tehran, in which Nafisi highlighted the nature of reading texts originating from an alien culture, and, in Hannah Arendt's footsteps, wished that the reading would change her students' thinking. Philip Goldstein contrasts reading practices that are also separated temporally. Focusing on possible readings of Richard Wright's Native Son, he attributes the change from seeing the text as a naturalist protest novel, to regarding Bigger Thomas's fate as an existential struggle that ends in liberation, to "the changing status of the 
naturalist and modernist movements and the emergence of black aesthetics" (120); then, surprisingly, he also suggests that it might be due to the evolving beliefs of the author himself. Going on to provide an outline of a brief history of literary criticism, the text (as Miller's and Goldstein's essays) suddenly erupts in a politically charged description of the present state of affairs, in which Goldstein sees "the modern university and the giant corporate media" (repeated twice, 130, 131) as the ultimate foe (Machor, "The American Reception of Melville's Short Fiction in the 1850s"; Mailloux, "Judging and Hoping: Rhetorical Effects of Reading about Reading"; Goldstein, "Richard Wright's Native Son: From Naturalist Protest to Modernist Liberation and Beyond").

The remaining three essays in this group, interestingly, all seem to revolve around the concepts of authenticity and realism as separate from contrasting strategies of "expert" reading. Modernism and the literature of the women's liberation movement alike appear to have been ridiculed by early reviews which accused them of being insincere, untrue, and inauthentic (Leonard Diepeveen, "Learning from Philistines: Suspicion, Refusing to Read, and the Rise of Dubious Modernism"; Charlotte Templin, "Discourses in Dialogue: The Reception of Alix Kates Shulman's Memoirs of an Ex-Prom Queen"). Critics and reviewers levelled the same accusations against Daniel Lewis James, who adopted the nom de plume Danny Santiago and authored a "deceptively" authentic Chicano novel, when his true identity as a white writer was revealed. Interestingly, both Marcial González, who reviews James's fate in his “Reception and Authenticity: Danny Santiago's Famous All over Town," and Templin, who investigates the reception of first generation feminist literature via Alix Kates Shulman's novel, fail to ask whether it was not the texts themselves, but preconceptions about the authors that were responsible for the apparent authenticity or its opposite which was sensed by early readers.

Researchers, however, might want to consider less scholarly or "expert" readers who do not (did not) regularly convert their readings into written accounts. In the case of readers still alive, there is the possibility of asking them to do so by conducting interviews or handing out questionnaires. This is the practice of Tony Bennett, who tests the post-Marxist theory of Pierre Bourdieu on class-based taste profiles on the data of actual sociological research. Unsurprisingly, he finds that statistical variations outweigh the vague tendency of higher classes to choose so-called high legitimacy cultural products. This finding problematizes Bourdieu's notion of the unity of class habitus, but it is a remark saved till the end of the essay that discredits Bourdieu altogether, who, in 1984, suggested that "nothing is more alien to working-class women than the typically bourgeois idea of making each object in the home the occasion for an aesthetic choice" (qtd. in Bennett, "Habitus Clivé: Aesthetics and 
Politics in the Work of Pierre Bourdieu" 77). Kenneth Roemer also makes use of the results of his research among presentday readers, but his interest lies in discovering how they react to an allegedly outdated utopia, Edward Bellamy's Looking Backward. His suggestion that the people who found it the easiest to relate to the text were the ones with experience of crossing cultures or of poverty provides an important insight into the interaction between reading and the personalities of readers ("Placing Readers at the Forefront of Nowhere: Reception Studies and Utopian Literature").

But what happens when one sets out to investigate the reception of "ordinary" readers who are no longer available for questioning? Such an analysis would usually turn to alternative sources following what Toby Miller termed an "archival" method (361). The "Archives" investigated might range from preserved fan mail, which provide the source for Amy L. Blair's account of the baffling success of Sinclair Lewis's Main Street among middlebrow readers, itself a novel satirizing middlebrow culture, to David Paul Nord's relation of the workings of the Bureau of Accuracy and Fair Play of the New York World, which dealt with newspaper readers' complaints. This latter essay might strike one as more a historical account than a paper belonging to reception studies, like Bennett's work, which, I believe, might find itself more at home in sociology. Problems inherent in this kind of approach already manifest themselves in Nord's account, where all the readers he considers turn out to be professional writers, journalists, or editors (Blair, "Main Street Reading Main Street"; Nord, "Accuracy or Fair Play? Complaining about the Newspaper in Early Twentieth-Century New York”).

This is also true of Barbara Hochman's essay entitled "Sentiment without Tears: Uncle Tom's Cabin as History in the 1890s," in which she regards paratextual elements and illustrations in later editions of Harriet Beecher Stowe's novel as indices to supposed or prescribed reading practices. Here, editors and illustrators are considered representative readers. Ellen Gruber Garvey does make a step toward finding the "ordinary" reader in history in her "The Power of Recirculation: Scrapbooks and the Reception of the Nineteenth-Century Press," as she focuses on scrapbooks containing newspaper clippings made during the Civil War. The three scrapbook-makers she scrutinizes, however, turn out to be as expert readers and writers as possible, with a suffragist newspaper columnist, a women's rights pioneer lecturer, and a publicly active abolitionist.

What is common in all these essays as they lack any other kind of sources concerning the readers - is the tendency to regard production as a form of reception. It is not only the selections of clippings or complaints which are read as readings; but actions traditionally regarded as production (illustration) or rewriting (editing) have also come under the umbrella of reception and indices to 
reading strategies. The need for this inclusion is understandable. But one might be tempted to think that all one has to do is to pair this argument with Barthes, according to whom there is no writing but re-writing: "the writer can only imitate a gesture that is always anterior, never original," to arrive at the conclusion that everything is, in fact, reading. ${ }^{3}$

This line of argument also surfaces in a non-historical context. Small talk is considered reception when Andrea Press and Camille Johnson-Yale analyse political conversation in a hair salon prompted by television shows in what might be called an ethnic, feminist, multimethod media reception study ("Political Talk and the Flow of Ambient Television: Women Watching Oprah in an African American Hair Salon"). Possibly because of the small number of cases considered, however, their conclusions, as are Hochman's and Garvey's, are somewhat weakened by speculations and self-contradictory elements in the sources.

One might also follow the opposite strategy to get around the problem of reading as something that might not be readily accessible. Just as it is possible to consider production reception, others appear to base their arguments on the idea that any kind of reception directly entails production, which has prompted mostly theoretical essays in this anthology. This train of thought seeks to activate the audience or the reader, turning it from a passive receptor into an active organizer, selector, and modifier of discourse.
Patrocinio Schweickart offers a development over Jürgen Habermas's theory of communicative action by complementing production as a communicative action with reading as a communicative action. Calling attention to the active role of readers / listeners in any communication, Schweickart shows that the symmetry among speakers envisaged by Habermas in an ideal setting of the creation of validity is, in fact, dependent upon an inherent asymmetry between speaker and listener, which Schweickart interprets via Nel Noddings's notion of care ("Understanding an Other: Reading as a Receptive Form of Communicative Action"). In a less theoretical account, however, the notion of the active audience immediately gets problematized. Rhiannon Bury, when considering discussions of a scene of dubious interpretation in one of the episodes of a TV series in her "Textual Poaching or Gamekeeping? A Comparative Study of Two Six Feet Under Internet Fan Forums," sets out to determine whether fans engage in deliberate misreadings of the "text," or are more interested in unearthing supposed authorial meaning. While she found that both intratextual and extratextual strategies were used to discover the "true" meaning, contributors to fan forums most often respected "the boundary between thoughtful speculation based on a close reading of the text and wild speculation based on personal whim" (303). In other words, actual readers were found less "active" than expected by many of the theoretical considerations. 
It is in Jack Bratich's essay entitled "Activating the Multitude: Audience Powers and Cultural Studies" that the so-called active audience moment gets the most extensive consideration. Focusing on the audience from an ontological point of view, Bratich suggests that early audience research tried to come to terms with "audience powers" not via the binary active / passive, but via the active / reactive. This coming-toterms was done, in Bratich's term, by splitting audience power into media and audience. This split is described using Antonio Negri's concepts constituent and constituted powers. "Constituent power is the immense pool of desire and action, the res gestae of subjective forces, that is the motor of history." Constituted power, on the other hand, "is the name given to forms and arrangements that constituent forces take" (35). Bratich argues that the audience has been wrongly constru(ct)ed as a merely reactive force by reversing the relationship between the two powers, and considering constituent power - the site of creative forces - wrongly, the result of constituted ones.

The re-reversal that would restore the "original" and desired state of affairs may remind one of Jacques Derrida's post-structuralist reversal of the order of speech and writing in order to point beyond logocentrism; just as the very notion of the constituent power manifesting itself in constituted ones is reminiscent of Derrida's différance "producing” differences. This différance, as it "precedes" all semantic structures, cannot be talked about. And, it seems, neither can constituent power. For it is precisely at the point where Bratich considers the consequences of analysing the active audience moment, using Negri's terms, that his language becomes fragmented and performative as opposed to cohesive and argumentative. But the parallels with Derrida do not end here. Derrida, when discoursing on différance, refers to protowriting; Bratich, when scrutinizing the constituent power, to prestructure. Moreover, both split (as rupture) and moment (as event) are there around Derrida's notion of decentering, which might be conceived of as both an event in history and something that has not yet been attained.4 Both propositions, as we shall see, are true for Bratich's active audience moment.

For after showing that the encoding / decoding model of communication and the very concept of the audience are the results of the split and the reversing of constituent and constituted powers, Bratich goes on to consider why active audience studies met with such hostility in academia. According to Bratich, active audience study ended up in a culde-sac because it became politicized when, following Marxist tenets, audience power was equated with consumer power, and production and reception were analysed in terms of commodification and consumption, which re-generated the very same split witnessed above: "constituent powers could 
operate only via the constituted power of the consumer" (43). But there is a way out of this cul-de-sac: by turning, finally, merely reactive audiences into genuinely active ones.

What is interesting to see here is that while many of the essays in the anthology call for, or operate within a framework that presupposes, in one sense or another, the activation of the reader, Jack Bratich's account, via the interpretation of early audience research and the analysis of the backlash against active audience studies, portrays this activation as a thing of the past. The end of his essay, however, appears to call for the very same activation: the transition from reactive to active. Just as decentering, or the death of the Author, audience activation might be conceived of as belonging either to ontology or history or methodology, or to all of these at the same time.

The problematization of the concept of the active audience, as well as its dubious place in history, has not prevented scholars from merging the two opposite strategies outlined above, and from suggesting that production and reception should, in fact, be viewed as unified, equated, and capable of being studied with the very same tools. Janet Staiger, when she analyses Robert Aldrich's film adaptation of Mickey Spillane's spy novel as a reading in her "Kiss Me Deadly: Cold War Threats from Spillane to Aldrich, New York to Los Angeles, and the Mafia to the H-Bomb," explicitly states not only that "one of the slogans for media studies has been to think of the media consumer as a producer" (279), but that she has been "exploring the application of the findings of media reception studies back to what is often seen as the other side of the producer-text-consumer equation" (280). Reading is taken to be writing; as writing (film adaptation) is now seen as a form of reading. But Staiger does not stop here: she meticulously considers the consequences of such an equation, and realizes that reception study still has to account for the inherent dissimilarity between producer and consumer in access to power and distribution, a dissimilarity that very much echoes Schweickart's usage of the notion of care. Perhaps even more importantly, Staiger points out a now glaring selfcontradiction that has arisen out of the history of literary criticism: that while special attention is granted to the reader's frame of mind, its now equal, the author, has been rendered mute by critics as an unreliable source on his or her own writing-reading.

Janice Radway's “What's the Matter with Reception Study? Some Thoughts on the Disciplinary Origins, Conceptual Constraints, and Persistent Viability of a Paradigm," which is more an account of personal difficulties encountered during her research that would read zines and friendship networks as culture consumption, stands as an unsettling question mark at the end of the anthology. Radway, too, sees the authority of the critic preserved even as the focus has moved from reading to reading reading, 
which statement also serves as a fundamental criticism against structuralism and cognitive poetics for upholding the status quo.

With the blurring of the borderline between production and reception, which, based on Bratich's account, might be called a poststructuralist or postmodern turn, practically nothing appears to be excluded from the scrutinizing gaze of reception studies as represented in this collection. From small talk to film adaptations, from illustrations to social networks, activities which have traditionally been classified as production are now analysed as reception of other artworks, media, or culture. And with readers and audiences activated, reception is no longer seen as passive decoding, but as an active contribution to discourse, in short, as production. But reception study has also extended itself by incorporating neighbouring realms of other disciplines. In line with the merging of literary and cultural (media) studies, a cursory glance over the background of the contributors to the present volume reveals the truly interdisciplinary nature of the field, interacting with, among others, sociology, media and communication studies. This expansion has indeed shown a way around the problem of reading readings, but this has not been without a price. With a concept of reception that now covers everything, reception study appears less and less separable from literary, media, or cultural studies in general.

Előd Pál Csirmaz
Notes

1. See, for example, Jonathan Culler, Structuralist Poetics: Structuralism, Linguistics and the Study of Literature (1975) (London: Routledge, 1997), and Cognitive Poetics in Practice, eds. Joanna Gavins and Gerard Steen (London and New York: Routledge, 2003).

2. See Seán Burke, The Death and Return of the Author (Edinburgh: Edinburgh UP, 1998), p. 26.

3. Roland Barthes, "The Death of the Author," trans. S. Heath, in Modern Criticism and Theory: A Reader, ed. David Lodge (London: Longman, 1988), 167-172, p. 170. 4. Jacques Derrida, "Structure, Sign and Play in the Discourse of the Human Sciences," trans. Alan Bass, in Critical Theory Since 1965, ed. Hazard Adams and Leroy Searle (Tallahassee: Florida State UP), 83-94.

\section{yBa Shorks}

Kieran Cashell, Aftershock: The Ethics of Contemporary Transgressive Art (London and New York: I. B. Tauris, 2009)

Aftershock is a novel, unique and slightly provoking attempt to canonize $\mathrm{yBa}$ art through a thorough theoretical analysis of the works of six artists: Richard Billingham, Marc Quinn, Marcus Harvey, The Chapman Brothers, Tracy Emin and Damien Hirst. Kieran Cashell operates with theories emerging from post-structuralism (Foucault, Bataille, Kristeva, Mulvey), which she productively amalgamates with recent theories of transgression (Jenks, Julius) ${ }^{1}$ in order 